\title{
Diversity and endemism of woody plant species in the Equatorial Pacific seasonally dry forests
}

\author{
Reynaldo Linares-Palomino • Lars Peter Kvist • Zhofre Aguirre-Mendoza • \\ Carlos Gonzales-Inca
}

Received: 7 October 2008/Accepted: 10 August 2009/Published online: 16 September 2009

(C) The Author(s) 2009. This article is published with open access at Springerlink.com

\begin{abstract}
The biodiversity hotspot of the Equatorial Pacific region in western Ecuador and northwestern Peru comprises the most extensive seasonally dry forest formations west of the Andes. Based on a recently assembled checklist of the woody plants occurring in this region, we analysed their geographical and altitudinal distribution patterns. The montane seasonally dry forest region (at an altitude between 1,000 and 1,100 m, and the smallest in terms of area) was outstanding in terms of total species richness and number of endemics. The extensive seasonally dry forest formations in the Ecuadorean and Peruvian lowlands and hills (i.e., forests below $500 \mathrm{~m}$ altitude) were comparatively much more species poor. It is remarkable though, that there were so many fewer collections in the Peruvian departments and Ecuadorean provinces with substantial mountainous areas, such as $\mathrm{Ca}-$ jamarca and Loja, respectively, indicating that these places have a potentially higher number of species. We estimate that some form of protected area (at country, state or private level) is currently conserving only $5 \%$ of the approximately $55,000 \mathrm{~km}^{2}$ of remaining SDF in the region, and many of these areas protect vegetation at altitudes below $500 \mathrm{~m}$ altitude. In contrast, the more diverse seasonally dry forests in mountainous areas remain little protected.
\end{abstract}

\footnotetext{
R. Linares-Palomino ( $\square)$

Department of Systematic Botany, University of Göttingen, Untere Karspüle 2, 37073 Göttingen, Germany

e-mail: r.linaresp@yahoo.co.uk

L. P. Kvist

Institute of Biology, University of Aarhus, Ny Munkegade 1540, 8000 Aarhus C, Denmark

Z. Aguirre-Mendoza

Herbario LOJA, Universidad Nacional de Loja, Ciudadela Guillermo Falconí E., Loja, Ecuador

C. Gonzales-Inca

Department of Biology and Environmental Sciences, University of Jyväskylä, P.O. Box 35, 40014 Jyväskylä, Finland

Present Address:

R. Linares-Palomino

Herbario Forestal MOL, Universidad Nacional Agraria La Molina, Apartado 456, Lima 1, Peru
} 
Keywords Biodiversity hotspot - Checklist - Conservation - Ecuador . Equatorial Pacific · Lowland dry forest - Montane dry forest · Peru · Tumbesian region

\author{
Abbreviations \\ SDF Seasonally dry forest \\ m.a.s.l Metres above sea level
}

\title{
Introduction
}

The Tumbes-Piura and Ecuadorian dry forests ecoregions, located in northwestern Peru and southwestern Ecuador, respectively, are two of the most important endemism zones in the world (Davis et al. 1997). High levels of endemism have been documented especially for birds (55 restricted range bird species; BirdLife International 2003). It has been assumed that plant endemism in the region rivals the levels reported for bird species, but apart from local studies and data (e.g., Dodson and Gentry 1991), no concluding evidence has been offered. These ecoregions, both covering ca. $62,000 \mathrm{~km}^{2}$, mostly support seasonally dry forest (SDF) vegetation (Dinerstein et al. 1995) and there is evidence that the use of these forests in Peru spans some 10,000 years (Hocquenghem 1998). In recent times, however, the intensity of forest conversion, degradation and destruction (e.g., Dodson and Gentry 1991; Parker and Carr 1992) has increased dramatically because of population expansion and immigration. The seasonality of the climate in this area, precluding the permanent incidence of pests, and the relative fertility of the soils made them a good choice for agricultural exploitation (Ewel 1986). Together, these factors threaten the existence of the SDF vegetation in Ecuador and Peru (Aguirre and Kvist 2005).

In response to this situation, the biological sciences community has begun to focus with increasing interest on the SDF (and adjacent) vegetation in Ecuador and Peru, highlighting their unique and threatened status (e.g., Best and Kessler 1995; Davis et al. 1997; Myers et al. 2000; Olson and Dinerstein 2002). The whole region is sometimes referred to as the Tumbes-Piura and Ecuadorian dry forests ecoregions (as defined in Olson et al. 2001). Since it has been shown to constitute a single phytogeographic unit (Svenson 1946; Linares-Palomino et al. 2003), a more appropriate and unifying term would be Equatorial Pacific region (Peralvo et al. 2007), and this is how we will refer to it throughout the text. Despite all the valuable efforts to increase the available information about plant diversity in this region, a drawback was that most studies were restricted to either Ecuador or Peru (e.g., Parker et al. 1985; CDC-UNALM 1992; Parker and Carr 1992; Josse and Balslev 1994; Cerón 1996a, b; Nuñez 1997; Klitgaard et al. 1999; Aguirre et al. 2001; Madsen et al. 2001; Cerón 2002; Aguirre and Delgado 2005; Linares-Palomino and Ponce-Alvarez 2005), with little information on cross-border characteristics of species or vegetation. Only recently, efforts have been made to study the Ecuadorean and northern Peruvian SDF as a unit, like the Pacific Equatorial Ecoregional Assessment (The Nature Conservancy et al. 2004) or the Peru-Ecuador Dry Forest Clearing-house Mechanism-DarwinNet (http:// www.darwinnet.org).

In accordance with this new vision of a phytogeographical unit, an annotated SDF woody plant checklist for Ecuador and northwestern Peru was recently published (Aguirre et al. 2006), providing information about the taxonomic status, distribution and selected 
ecological characteristics of each species reported in Ecuadorean and northern Peruvian SDFs. The information contained in this database, as well as the peculiar geography of the region, prompted questions about the patterns of distribution of species richness and endemism. The aim of this paper is to analyse the diversity and distribution of the woody flora of the Equatorial Pacific dry forest ecoregion to answer the following questions: How does the floristic composition and diversity of the SDF in the Equatorial Pacific region compare to other vegetation in the Neotropics? How is the diversity of woody plants distributed amongst areas and elevational bands? Are the species adequately protected within the protected area networks in the region? These questions will also be addressed for endemic species. In addition, we used the checklist to assess the conservation status of the woody component of the Ecuadorean and Peruvian SDFs.

\section{Methods}

\section{Study area}

We used the term SDF in a very broad sense, including a complex mosaic of vegetation formations raging from wide-open savannah-like forests, to closed canopy semi-deciduous variants. Our study area included both the Tumbes-Piura and Ecuadorian dry forests ecoregions as defined by Olson et al. (2001) and also adjacent SDFs from the Loja province in Ecuador and the Cajamarca department in Peru (Fig. 1). The centre of our study area, in the provinces of El Oro and Loja (Ecuador) and the departments of Tumbes and Piura (Peru), constitutes the most extensive and continuous area of SDF west of the Andes. Fragmented and isolated forest patches along the coast and the lower western Andean slopes constitute the remaining SDF vegetation north (provinces of Los Rios, Manabí and Esmeraldas in Ecuador) and south (departaments of Lambayeque, La Libertad and Cajamarca in Peru) of this centre. Defined this way, SDFs cover around 55,000 km² (Aguirre and Kvist 2005). Annual rainfall values are highly variable in this extensive area (from below $250 \mathrm{~mm}$ in the areas adjoining the Sechura desert in Piura, Peru to 2,000 $\mathrm{mm}$ in northern Esmeraldas, Ecuador), not least because of the influence of El Niño-Southern Oscillation events (Ortlieb and Macharé 1993). Rainfall seasonality is another important factor influencing the vegetation, varying from 3 to 8 months in which no rain occurs. Much of the studied region covers areas below 400 m.a.s.l., including extensive plains and low hills in the west. The topography becomes more dissected and increases in altitude towards the interior of the continent where the foothills of the Andes begin. SDF vegetation is present all along this altitudinal range, from sea level to 1,600-1,800 m.a.s.l. in the montane SDFs of Loja (Lozano 2002) and to 1,800 m.a.s.l. in the montane SDFs of the western Andes in Peru (Weberbauer 1945).

\section{Data analyses}

The analyses presented here were based on a list containing 313 woody species (180 genera and 54 families) reported for the Equatorial Pacific SDF ecoregion in Ecuador and Peru (Aguirre et al. 2006). The regularly updated list (last update in September 2008) included woody species reported in inventories and obtained from herbarium data, taxonomic monographs and revisions. We only included species that reach at least $3 \mathrm{~m}$ during some time in their life cycle. We also defined an altitudinal limit of 1,100 m.a.s.l. for our 
Fig. 1 Topographical characteristics of the Pacific Equatorial region and major political units in Ecuador (provinces) and Peru (departamentos)

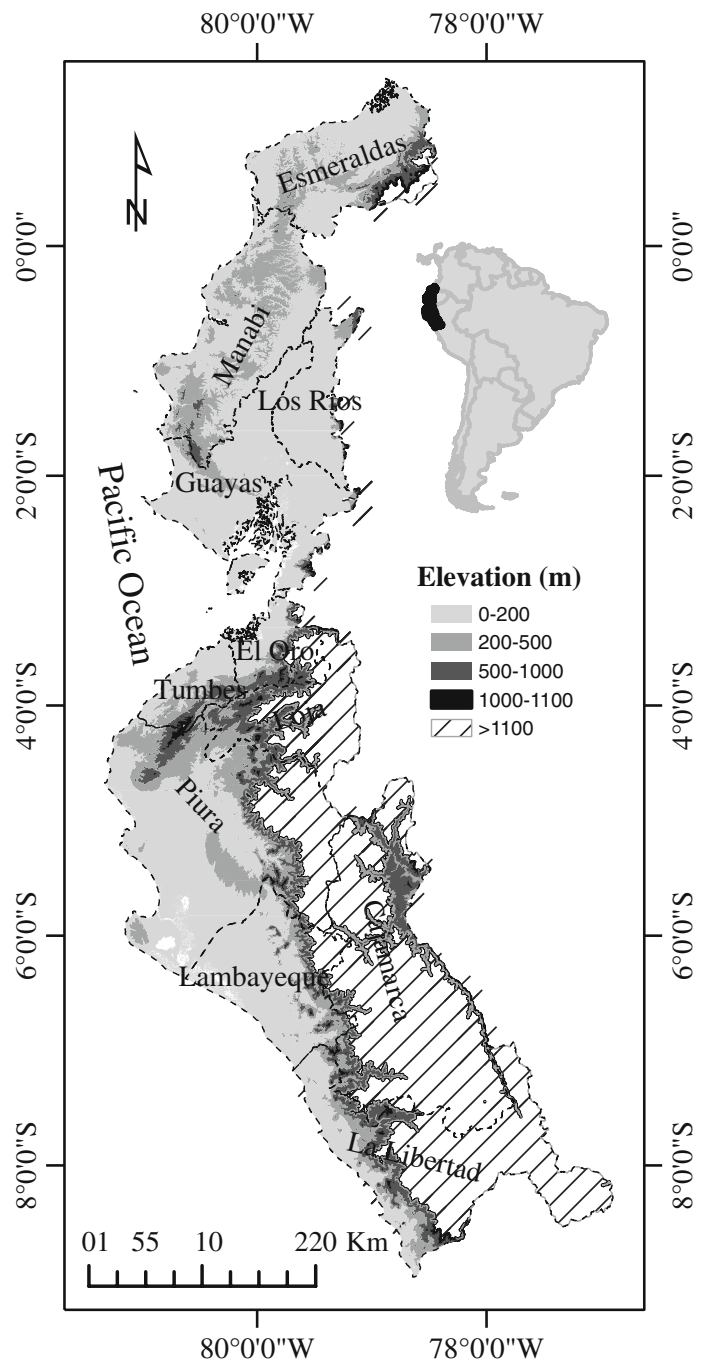

study area in order to exclude dry Andean and Puna vegetation from higher altitudes, which gradually intermingles with SDF vegetation at this altitude, especially in the dry inter-Andean valleys. Geographical and altitudinal distribution was assessed and complemented with Jørgensen and León-Yánez (1999) and Bracko and Zarucchi (1993), including the latest additions for both countries (Ecuador: 2000-2004, Ulloa Ulloa and Neill 2005; Peru: 1993-2003, Ulloa Ulloa et al. 2004). We define endemism at two levels: first, we identify endemic species restricted to either Ecuador or Peru; second, we identify, and consequently consider as endemic, those species restricted to the Equatorial Pacific region. We were not able to find accurate altitudinal distribution data for 29 Ecuadorean species (including four endemics) and for two Peruvian species. We excluded them from the quantitative analyses requiring altitude data. Endemism and conservation assessment were checked with Valencia et al. (2000) for Ecuador, León et al. (2006) for Peru, and the online IUCN Red List database (IUCN 2006). 
Lozano (2002) in southern Ecuador and Weberbauer (1945) in northern Peru classified the vegetation into different altitudinal bands, each having a distinctive floristic composition. Following their schemes, we performed an analysis of the elevational distribution of the woody SDF species by assigning them to four broad elevational categories: 0-200 m, 200-500 m, 500-1,000 m, 1,000-1,100 m. Even though we restricted our study to areas below 1,100 m.a.s.l., several species, which are characteristic for SDFs below this altitude, easily reach higher elevations, as for example in the Peruvian inter-Andean valleys (e.g., Weberbauer 1945). We calculated the area of each altitudinal band in a GIS using the Shuttle Radar Topography Mission (SRTM) DEM data, with a resolution of $90 \mathrm{~m}$ (Jarvis et al. 2008), projected onto a planar coordinate system (UTM 17S, Datum WGS84). To estimate the total area of SDF in each political unit, we also calculated the total departmental or provincial area in the range $0-1,100$ m.a.s.l. We worked with two values, first, the absolute number of species in each altitudinal band; second, the density of species per $1,000 \mathrm{~km}^{2}$. The latter value, allowed us to assess if there were differences in absolute species richness or endemism per unit area. We also looked at the patterns of species distributions in the major geopolitical units (provinces in Ecuador, departments in Peru, cf. van der Werff and Consiglio 2004).

We follow the Angiosperm Phylogeny Group (APG [Angiosperm Phylogeny Group] 2003), thus treating Leguminosae (including Caesalpinaceae, Mimosaceae and Papilionaceae) and Malvaceae (including Bombacaceae, Sterculiaceae, Tiliaceae and Malvaceae) sensu lato. Buddlejaceae is included in Scrophulariaceae, Cecropiaceae in Urticaceae, Flacourtiaceae in Salicaceae. For nomenclature, we follow the Missouri Botanical Garden's TROPICOS online database.

\section{Results}

We found 193 species reported in both countries, 272 species for Ecuador (79 reported only for Ecuador) and 234 species for Peru (41 reported only for Peru). The most speciesrich family was Leguminosae with 70 species, followed by Malvaceae (19 species) and Boraginaceae, Cactaceae and Moraceae (12 species each). The most genera-rich families were Leguminosae and Malvaceae (with 34 and 15 genera, respectively), followed by Verbenaceae, Euphorbiaceae (both with 8 genera) and Cactaceae (7 genera) (Table 1). Most families were represented by few species. The 11 most speciose families (Table 1) accounted for 182 species (58\% of the total) and 92 genera (51\% of the total). Thirteen families were included having only one woody species present in SDFs in the region: Acanthaceae, Agavaceae, Bixaceae, Burseraceae, Celestraceae, Combretaceae, Ebenaceae, Monimiaceae, Olacaceae, Oleaceae, Opiliaceae, Polemoniaceae, Rosaceae.

We identified 67 species, which are endemic to either Ecuador (17 species), Peru (16 species) or the Equatorial Pacific region (34 species) (Table 2). Most of them are typical for SDF vegetation, although some are also found in other vegetation types. Leguminosae is the family with most endemics (15 species), followed by Cactaceae ( 7 species) and Malvaceae (6 species). Thirty-four species have been assigned an IUCN red list category, 31 of which are also endemic to Ecuador, Peru or the Equatorial Pacific region (Appendix 1). The other three species (e.g., Cedrela odorata) are also very well represented in neotropical SDF, but have a wider geographical distribution.

The altitudinal distribution of absolute species richness in the Equatorial Pacific region showed more or less a constant pattern with similar values in the altitudinal bands below 1,000 m.a.s.l. (Fig. 2a; Appendix 2). In the montane altitudinal band, however, species 
Table 1 Diversity and endemism of the most species and genera rich families in the seasonally dry forests of Ecuador and Peru

In parenthesis percentage of the total species count for each family

\begin{tabular}{lrcl}
\hline & No. genera & No. species & $\begin{array}{l}\text { No. endemic } \\
\text { species }\end{array}$ \\
\hline Total (54 Families) & 180 & 313 & $67(21)$ \\
Leguminosae & 34 & 70 & $15(21)$ \\
Malvaceae & 15 & 19 & $6(32)$ \\
Boraginaceae & 2 & 12 & 0 \\
Cactaceae & 7 & 12 & $7(58)$ \\
Moraceae & 4 & 12 & $3(25)$ \\
Verbenaceae & 8 & 11 & 0 \\
Bignoniaceae & 5 & 10 & $3(30)$ \\
Capparaceae & 2 & 10 & $1(10)$ \\
Euphorbiaceae & 8 & 10 & $4(40)$ \\
Meliaceae & 4 & 8 & 0 \\
Polygonaceae & 3 & 8 & $5(63)$ \\
\hline
\end{tabular}

Table 2 Species distribution by geopolitical unit, provincia (P) in Ecuador or department (D) in Peru

\begin{tabular}{lllll}
\hline No. of P/D & Total no. species & EC + PE endemics & EC endemics & PE endemics \\
\hline $\begin{array}{l}\text { Total number } \\
\text { of species }\end{array}$ & 313 & 34 & 17 & 16 \\
1 & $41(13.1)$ & $1(2.9)$ & $7(41.2)$ & $9(56.3)$ \\
2 & $45(14.4)$ & $3(8.8)$ & $2(11.8)$ & $5(31.3)$ \\
3 & $34(10.9)$ & $2(5.9)$ & $4(23.5)$ & $1(6.3)$ \\
4 & $41(13.1)$ & $6(17.6)$ & $0(0)$ & $1(6.3)$ \\
5 & $29(9.3)$ & $7(20.6)$ & $4(23.5)$ & $0(0)$ \\
6 & $42(13.4)$ & $5(14.7)$ & $0(0)$ & $0(0)$ \\
7 & $36(11.5)$ & $2(5.9)$ & $0(0)$ & $0(0)$ \\
8 & $23(7.3)$ & $4(11.8)$ & $0(0)$ & $0(0)$ \\
9 & $12(3.8)$ & $1(2.9)$ & $0(0)$ & $0(0)$ \\
10 & $9(2.9)$ & $3(8.8)$ & $0(0)$ & $0(0)$ \\
11 & $1(0.3)$ & $0(0)$ & $0(0)$ & $0(0)$ \\
\hline
\end{tabular}

In parenthesis the percentage of the total number of woody or endemic species

a Calliandra trinervia has been reported for Tumbes (Peru) and is very likely found also in adjacent El Oro (Ecuador), but no voucher is mentioned (Barneby 1998), same situation applies for Eriotheca discolor, found mainly in Tumbes and Piura (and reported also in another three departments in Peru), but no voucher reported for adjacent provinces in Ecuador (R. Linares-Palomino, unpub. data)

richness decreased by about 50 species. Species richness in Ecuador peaked in the hills and decreased slightly towards the coastal lowlands and substantially towards higher altitudes. In Peru, species richness increased from the coastal lowlands towards the sub-montane region and decreased in the montane region. The endemic species in Ecuador and Peru showed a similar pattern to overall woody species richness in each country (Fig. 2b; Appendix 2). Species endemic to the Equatorial Pacific region, however, increased from the lowlands to the sub-mountains, and decreased substantially in the montane region. Values of woody species density (Fig. 2c; Appendix 2) and endemic species density (Fig. 2d; Appendix 2) per $1,000 \mathrm{~km}^{2}$ of each altitudinal band, showed that there were 

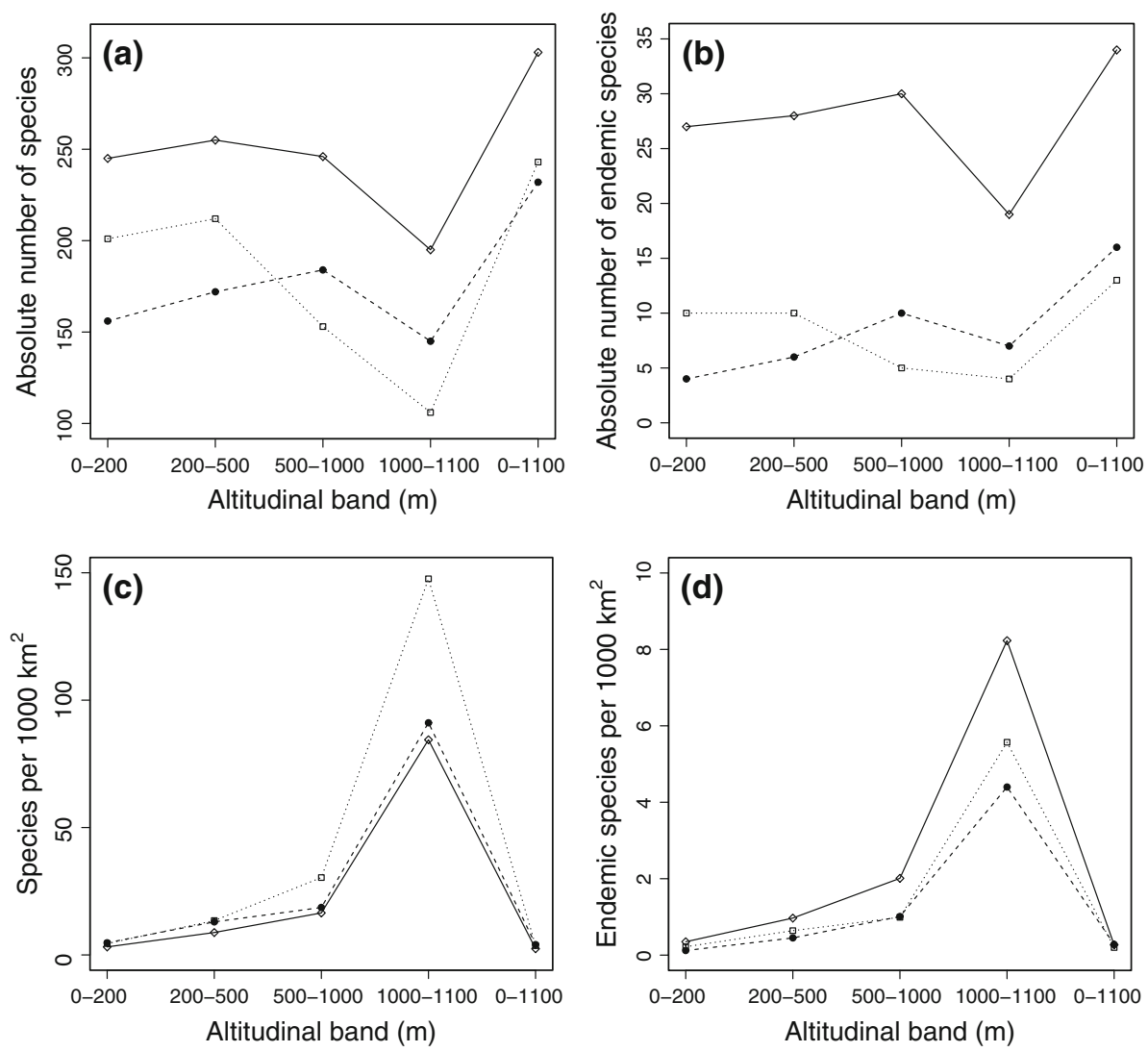

Fig. 2 Altitudinal distribution of absolute woody (a) and endemic species richness (b). Number of woody (c) and endemic species (d) per $1,000 \mathrm{~km}^{2}$. Note the different $y$-axis scales. Solid line Pacific Equatorial region, dotted line Ecuador, dashed line Peru

substantially more species and endemics per unit area in the montane region than at any other altitude in Ecuador, Peru or the Equatorial Pacific region. The lowest total species and endemics density values were in the lowlands of Ecuador, Peru and the Equatorial Pacific region.

Total area of the geopolitical units had no effect on total vascular plant species numbers, or on woody SDF species and endemics (Pearson correlation values of $0.16,-0.20$ and 0.37 , respectively, all non-significant, $n=11)$. The total area between sea level and 1,100 m.a.s.l. had no effect on woody SDF species and endemics (Pearson correlation values of -0.13 and 0.0 , respectively, all non-significant, $n=11$ ). The analysis of species distribution by geopolitical unit showed that half of all species $(51.4 \%)$ have been reported in four or less provinces or departments (13.1\% in only one) (Table 2). Endemic species restricted to either Ecuador or Peru showed an extremely local distribution, 41.2 and $56.3 \%$ of them having been found in only one province or department, respectively; and all of them in four or less provinces or departments. Endemics of the Equatorial Pacific area showed a wider distribution, half of them (18 species, 52.9\%) having been reported in four to six provinces and departments. 
Loja, Guayas, Manabí, Tumbes, El Oro and Cajamarca were the provinces and departments with most species (Table 3). The ratio woody SDF plants to total vascular plants is especially high in Tumbes. More than a third $(37 \%)$ of the vascular plants reported for this department are characteristic of the woody SDF vegetation. Loja province had most endemics (40 species), most of which are endemic to the Equatorial Pacific region (28 species), followed by the adjacent department of Tumbes (38 endemic species, 29 endemic to the Equatorial Pacific region). In contrast, Esmeraldas province and La Libertad department, where only small fragments of SDF remain, had only seven endemic species each. Country-level endemism showed that Loja and Guayas had most endemics in Ecuador (12 and 11 species, respectively), and Tumbes (9 species) in Peru. The ratio woody SDF endemics versus total vascular plant endemics showed that Tumbes had a substantial percentage of the endemics reported for that department in the SDF vegetation. Woody SDF endemics per $1,000 \mathrm{~km}^{2}$ of the study area were highest in Loja, Tumbes and El Oro (Table 3). Collection intensity, i.e., the number of collections per species of woody plants in the SDFs, has been highest in Guayas (ca. eight collections per species), Tumbes (ca. six collections per species) and Manabí (ca. five collections per species). Lowest collection intensity was in the SDFs of Piura.

\section{Discussion}

Patterns of species richness, endemism and distribution

In the first comprehensive review of the floristics of neotropical SDF Alwyn Gentry (1995) noted that SDF ecosystems were less species rich and contained only a subset of the plant diversity found in the more humid forests. The lower diversity in the Equatorial Pacific SDFs is clearly due to the low levels of diversity within families and genera. A notable exception is Leguminosae. This family showed high levels of diversity at the generic (34 genera, $19 \%$ of the total), specific (70 species, $22 \%$ of the total) and endemic species level (15 endemics, $21 \%$ of the total). This is not surprising since several studies have shown that this family is among the most, if not the most, prominent members of SDF in the Neotropics (Gentry 1995; Pennington et al. 2006). Malvaceae, on the contrary, are not necessarily regarded as important constituents of tropical dry forest communities (Pennington et al. 2006). Our data indicated that it is by far the second most important family contributing to the number of genera (15 genera, $8 \%$ of the total), species (19 species, $6 \%$ of the total) and endemic species (6 species, $9 \%$ of all endemics), although our results were based on an expanded Malvaceae concept (including 14 species from the former Sterculiaceae, Tilliaceae and Bombacaceae). Especially interesting was the subfamily Bombacoideae, contributing with several taxa (9 species, 6 genera). Gentry (1993), referring to the northern Peruvian SDFs already stated, "Fabaceae is the most speciose and dominant family of trees. Bombacaceae, though less speciose, are represented by five different genera of large trees and are probably more dominant here than elsewhere on earth", a statement that we can certainly extend to the SDFs in the Equatorial Pacific region. A narrow concept of Malvaceae would place Boraginaceae, Cactaceae and Moraceae in second place, all with 12 species.

In contrast to the low generic and specific diversity (as compared to humid rainforests), levels of endemism seem to be among the highest in the continent. We found 67 endemic species, which represent $21 \%$ of the total of woody SDF species reported in the Equatorial 


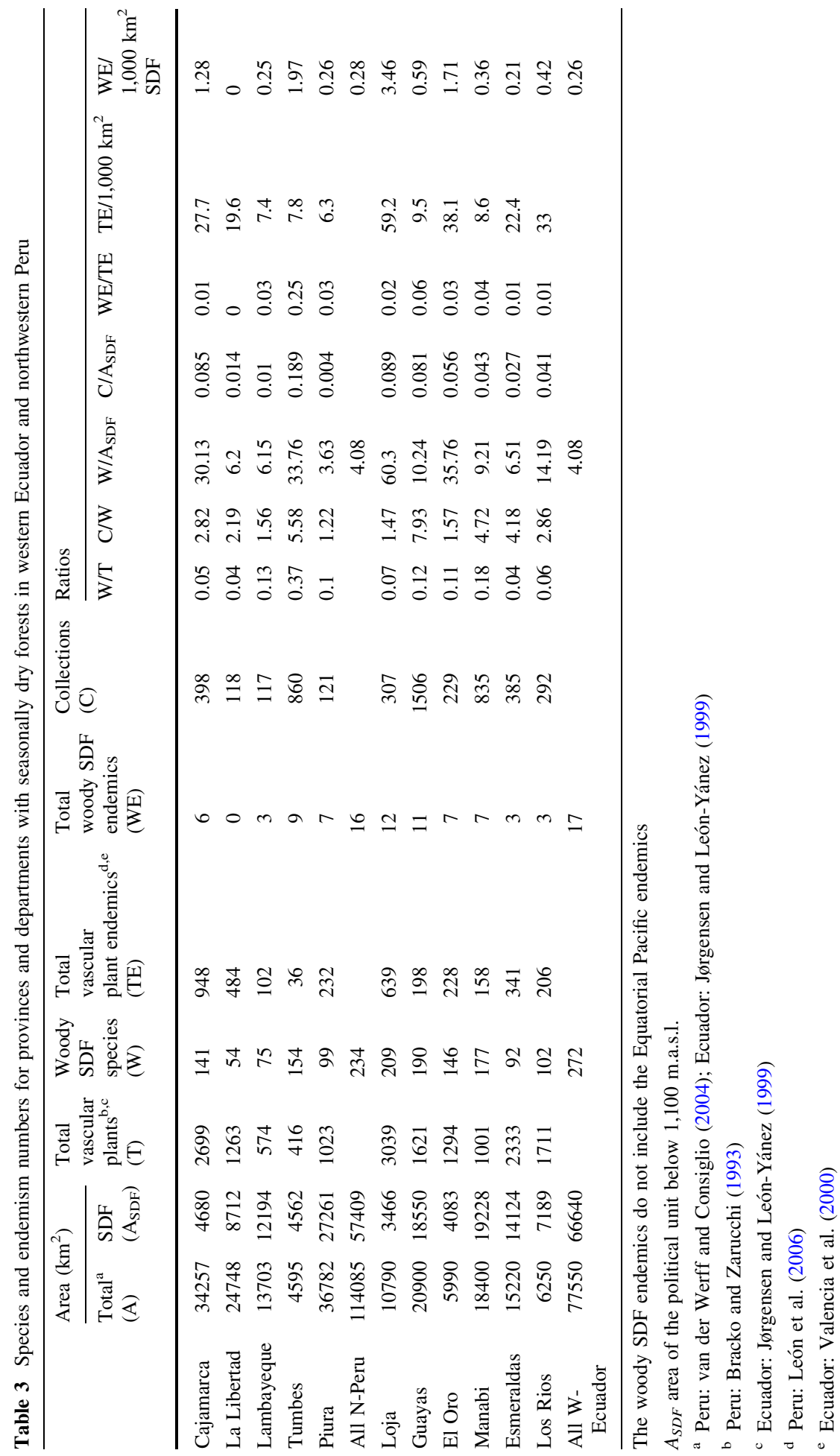


Pacific region. This percentage is similar to what Dodson and Gentry (1991) reported for the flora of a SDF in Ecuador and similar to their total estimate for the entire dry forest region in western lowland Ecuador. Considering only SDFs, they estimated that $19 \%$ of the species should be endemic (approximately 190 species). The whole flora of the region, including other vegetation types below 900 m.a.s.l., was estimated at some 6,300 vascular plant species, of which $20 \%$ or 1,260 species would be strictly endemic to the region (Dodson and Gentry 1991). Kvist et al. (2004) found similar levels of endemism for the Gesneriaceae in Ecuador (23 of 107 species). These endemism levels are very similar to what Gentry (1982) estimated for the Chocó flora, one of the worlds most publicised regions in terms of plant diversity and endemism. It was recently that the Equatorial Pacific SDFs and the Chocó were jointly considered as one of the hotspots of biodiversity in the world, (Mittermeier et al. 2005), with an estimated endemism level of 25\%. This estimation seems to hold true, at least for the woody component of the Equatorial Pacific SDFs.

There is little comparable information about levels of endemism in other SDF regions in the Neotropics as most data are from local checklists and inventories (e.g., Lott and Atkinson 2006 for SDF floristic checklists in Mexico and Central America). Available data suggest that the Equatorial Pacific SDFs are intermediate in levels of endemism as compared to other SDF regions. The Chiquitano SDFs in eastern lowland Bolivia seems to have the lowest endemism level of all neotropical SDF regions with only three endemic woody species out of 155 reported trees, a fact probably explained by the recent geological past of the area into which the extant flora arrived from more northerly latitudes after the last glacial maximum (Killeen et al. 2006). Intermediate levels of endemism have been reported for the dry Andean valleys in Bolivia, where $18 \%$ of the total native flora is considered endemic (López 2003). A study of three plant families (Labiatae, Asclepiadaceae, Acanthaceae) in the same region showed higher levels of endemism (33\%), although care has to be taken to extrapolate these figures as there is ample variation in the level of endemism between different families (Wood 2006). The highest levels of endemism in neotropical SDFs have been found in the Brazilian Caatinga and in Mexico. In the former, $41 \%$ of the 932 known plants are endemic (Silva et al. 2003), whereas $52 \%$ of the species of Leguminosae, the most important and dominant SDF family in the Neotropics, are restricted to this biome (Queiroz 2006). Finally, Mexican SDFs are estimated to have $60 \%$ of endemic species (Rzedowski 1991).

Both countries have also variants of inter-Andean SDF, which are best represented in the long and deep valleys of Peru. The most important of these dry valleys, the Rio Marañon valley, is located east of the northwestern Peruvian coastal SDF and connected to them by the lowest mountain pass of the whole Andean chain, the Porculla Pass (2,165 m.a.s.l.). It has been suggested, that this pass has favoured the immigration and exchange of SDF biota, which evolved either in the Marañon valley or the coastal SDF (woody plants: Linares-Palomino et al. 2003; birds: BirdLife International 2003, herpetofauna: Venegas 2005). Thus, the strong presence of a group of woody species in the data, which are preferentially found at altitudes above 1,000 m.a.s.l., could be composed of species that are also found in the Marañon valley. Indeed, several species show distributions extending into this valley (e.g., Eriotheca discolor, Erythroxylum novogranatense, Loxopterygium huasango, Trichilia tomentosa, Clavija euerganea, Mauria heterophylla, Inga oerstediana).

The altitudinal distribution of woody species and endemics showed two interesting relationships. In terms of absolute species numbers and endemics, the much more 
extensive coastal lowlands reported higher values than the sub-montane and mountainous areas. Nevertheless, once the effect of area had been taken into account by using the density of species per $1,000 \mathrm{~km}^{2}$, instead of absolute species numbers, an opposite pattern emerged, showing that species richness and endemics per unit area were highest in the mountains, and decreased substantially towards the lowlands. Similar results, although for greater elevational gradients (sea level to tree-line and above) and across several major vegetation types, were obtained by Borchsenius (1997) and van der Werff and Consiglio (2004) for the vascular floras of Ecuador and Peru, respectively. Both studies found that the density of endemic and restricted-range species was greater in the Andes than in the lowland areas on either side of these mountains. Furthermore, Borchsenius' study suggested that the southern Andes, part of which is included in our study area, appeared to be particularly rich in endemic species.

The geographical analysis by political units showed some interesting results. Loja, Cajamarca and Esmeraldas are the units where most vascular plants have been reported (with total vascular plant endemics highest in Cajamarca and Loja, Bracko and Zarucchi 1993; Jørgensen and León-Yánez 1999). In terms of woody SDF species, it seems that apart from Tumbes, Loja, El Oro and Cajamarca, the SDFs in the other regions appear to have been little collected. In addition, the high ratios of total vascular plants to woody SDF plants and of woody SDF endemics to total vascular plant endemics in Tumbes make this region probably the best representative of SDF vegetation in the study area.

The geographical distribution analysis showed that a substantial amount of the species, non-endemics $(27.5 \%)$ and especially endemics $(52.9-87.5 \%)$, have been reported in less than two provinces or departments. In some cases, this might be the result of little collecting (see below), but in the case of the endemic species, these are by definition restricted to a certain area and sometimes, within this area, they are rare and local. In the SDFs of the region, we face the severe problem of habitat destruction and some estimations consider that less than 5\% of the area remains forested (BirdLife International 2003). The rarity of some species and habitat reduction potentially threatens the SDF. This could enhance socalled "Centinelan extinction" events, i.e., the disappearance of rare and restricted species due to forest clearance (after the disappearance of several endemic species in Cerro Centinela, Ecuador, Dodson and Gentry 1991; Wilson 1992). In contrast to this countrylevel definition of endemism, endemic species to the Tumbesian region have much wider geographical distributions (e.g., Aeschynomene tumbezensis, Carica parviflora, Tabebuia bilbergii, Eriotheca ruizzi and Pithecellobium excelsum). All five are characteristic (and in some cases dominant) trees and shrubs of the SDF in Ecuador and Peru, but not found outside this region.

Collection intensity of woody plants in the Equatorial Pacific region at altitudes below 1,100 m.a.s.l. has been unequal. This is a result of the efforts of individual botanists or institutions concentrating on specific areas in the region (cf. Borchsenius 1997). The SDFs in Guayas and Tumbes have benefited from thorough work from botanists from the Missouri Botanical Garden (D. Neill in Guayas, C. Díaz in Tumbes, respectively). The Manabí SDFs have good collections due to intensive collecting from Ecuadorean botanists (e.g., Hernández and Josse 1997). Esmeraldas has recently seen intensive collection efforts as part of a Smithsonian Institution project to inventory the flora of the Mache-Chindul Mountains (Clark et al. 2006). The other SDF areas are relatively little surveyed, as can be seen from the density of collections. It is rather surprising that otherwise well-botanised regions like Cajamarca (e.g., Sagástegui 1995) and especially Loja (Aguirre et al. 2002) lag so much behind other regions in our analyses. This shows that even though the Andean 
flora from these regions has been comparatively well collected, efforts need still to be made to increase the knowledge of other vegetation types occurring in them.

\section{Conservation}

Dry lowland or Andean vegetation formations usually lack representation in protected area systems (e.g., Borchsenius 1997; López and Zambrana-Torrelio 2006). This is especially true in the SDF of Ecuador and Peru. There are 16 protected areas in the Equatorial Pacific region covering some $5,200 \mathrm{~km}^{2}$, and some of these are not completely covered by SDF (e.g., the Santuario Nacional Manglares de Tumbes and Reserva Ecológica ManglaresChurute are mainly mangroves; PN Cerros de Amotape includes an extensive area which covers a more humid variant of seasonal forests, as does the Mache-Chindul Ecological Reserve). Thus, the true extension of protected SDF in the region is probably around $2,500 \mathrm{~km}^{2}$, which represents approximately $5 \%$ of the estimated $55,000 \mathrm{~km}^{2}$ of remaining $\mathrm{SDF}$ in the region. This is, however, an optimistic estimate since the vegetation these areas protect is not necessarily intact forest. It may sound contradictory, but several of them are composed of secondary highly disturbed regenerating vegetation (e.g., Josse 1997). Only forests on very steep slopes and areas of very difficult access remain close to undisturbed vegetation. Unfortunately, these are few. Due to the constant growing population in the region and the consequent demand for new arable and habitable land, the establishment of new protected areas in near-pristine vegetation is difficult. The development of initiatives such as the Northwestern Biosphere Reserve in Peru (which includes the PN Cerros de Amotape, RN Tumbes and CC El Angolo) should be an opportunity, especially since they conserve important areas of the Tumbes and Piura department (including an elevational gradient from sea level to 1,600 m.a.s.l.), which, as has been shown above, concentrate some of the most characteristic SDFs of the region. An extension of it into adjacent protected areas of Ecuador as a transboundary biosphere reserve, a conservation figure specifically encouraged by the 'Seville +5 ' UNESCO-MAB meeting (UNESCO-MAB 2002), should be given highest priority. This step might not only enhance the conservation value of the region, but also provide a much more extensive corridor for the movement of organisms and better coordination of conservation tasks between both countries.

Acknowledgements Max Weigend, Jürgen Kluge and an anonymous reviewer provided suggestions and comments to improve the manuscript. Robert E. Magill provided access to the Peru Checklist data at the Missouri Botanical Garden. RLP acknowledges financial support from the UK Darwin Initiative for the project "Tree diversity and conservation priorities in Peruvian seasonally dry tropical forests", during which the Peru database was generated. The BEISA project (Biodiversity and Economically Important Species in the Tropical Andes, funded by DANIDA) supported the systematisation of information by ZAM and LPK. Personnel and volunteers of the Loja Herbarium helped during various stages of generation and collation of information. ZAM thanks the Universidad Nacional de Loja for support during this research.

Open Access This article is distributed under the terms of the Creative Commons Attribution Noncommercial License which permits any noncommercial use, distribution, and reproduction in any medium, provided the original author(s) and source are credited.

\section{Appendix 1}

See Table 4. 
Table 4 Woody species of seasonally dry forest in Ecuador (EC), Peru (PE) and the Equatorial Pacific region (EP) included in the Red List of threatened species of the IUCN

\begin{tabular}{|c|c|c|c|}
\hline Family & Species & Endemic & IUCN red list \\
\hline Malvaceae-Bomb. & Pseudobombax guayasense & $\mathrm{EC}$ & DD \\
\hline Malvaceae-Bomb. & Pseudobombax millei & $\mathrm{EC}$ & DD \\
\hline Meliaceae & Cedrela fissilis & & EN \\
\hline Anacardiaceae & Mauria membranifolia & $\mathrm{EC}$ & EN \\
\hline Erythroxylaceae & Erythroxylum ruizii & $\mathrm{EC}$ & EN \\
\hline Leguminosae-Papilionoideae & Clitoria brachystegia & $\mathrm{EC}$ & EN \\
\hline Monimiaceae & Siparuna eggersii & $\mathrm{EC}$ & EN \\
\hline Euphorbiaceae & Croton rivinifolius & $\mathrm{EC}$ & EN \\
\hline Capparaceae & Capparis heterophylla & EP & EN \\
\hline Oleaceae & Priogymnanthus apertus & $\mathrm{EC}$ & EN \\
\hline Leguminosae-Mimos. & Mimosa townsendii & $\mathrm{EC}$ & EN \\
\hline Asteraceae & Verbesina pentantha & $\mathrm{EC}$ & NT \\
\hline Euphorbiaceae & Croton menthodorus & $\mathrm{EC}$ & NT \\
\hline Euphorbiaceae & Croton wagneri & $\mathrm{EC}$ & NT \\
\hline Meliaceae & Schmardaea microphylla & & VU \\
\hline Meliaceae & Cedrela odorata & & VU \\
\hline Theophrastaceae & Clavija pungens & $\mathrm{EC}$ & VU \\
\hline Leguminosae-Caesalpinioideae & Bauhinia augusti & & VU \\
\hline Sapotaceae & Pradosia montana & EP & VU \\
\hline Cactaceae & Browningia albiceps & PE & DD \\
\hline Polygonaceae & Ruprechtia aperta & PE & DD \\
\hline Polygonaceae & Ruprechtia obovata & PE & DD \\
\hline Rhamnaceae & Ziziphus piurensis & PE & DD \\
\hline Myrtaceae & Eugenia quebradensis & PE & EN \\
\hline Myrtaceae & Psidium rostratum & PE & EN \\
\hline Myrtaceae & Psidium rutidocarpum & PE & EN \\
\hline Cactaceae & Armatocereus oligogonus & PE & $\mathrm{NE}$ \\
\hline Celastraceae & Maytenus durifolia & PE & VU \\
\hline Erythroxylaceae & Erythroxylum pacificum & PE & VU \\
\hline Lauraceae & Ocotea piurensis & PE & VU \\
\hline Polygonaceae & Ruprechtia peruviana & PE & VU \\
\hline Cactaceae & Neoraimondia arequipensis & PE & $*$ \\
\hline Leguminosae-Mimosoideae & Calliandra tumbeziana & PE & $*$ \\
\hline Leguminosae-Papilionoideae & Coursetia tumbezensis & PE & $*$ \\
\hline
\end{tabular}

$D D$ Data deficient, $E N$ Endangered, $N T$ Near threatened, $V U$ Vulnerable

*These endemic taxa have been included in the Red Data book of endemic plants in Peru (León et al. 2006), but have not been assigned an IUCN category yet

\section{Appendix 2}

See Table 5 . 


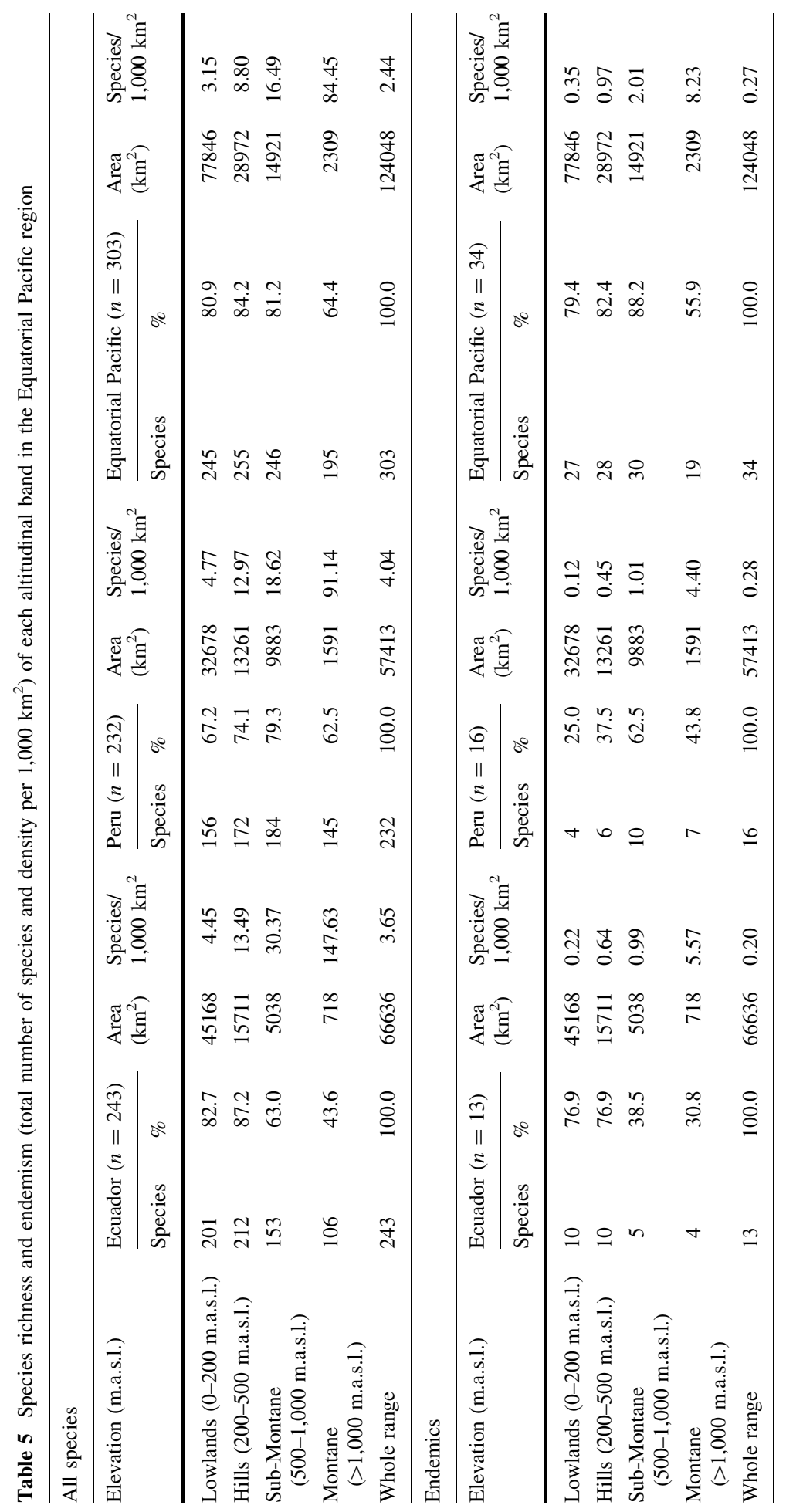




\section{References}

Aguirre Z, Delgado T (2005) Vegetación de los bosques secos de Cerro Negro-Cazaderos, Occidente de la Provincia de Loja. In: Vásquez MA, Freira JF, Suárez L (eds) Biodiversidad en los bosques secos de la zona de Cerro Negro-Cazaderos, occidente de la provincia de Loja: un reporte de las evaluaciones ecológicas y socioeconómicas rápidas. EcoCiencia, MAE y Proyecto Bosque seco, Quito

Aguirre Z, Kvist LP (2005) Composición florística y estado de conservación de los bosques secos del suroccidente del Ecuador. Lyonia 8:41-67

Aguirre Z, Cueva E, Merino B (2001) Evaluación ecológica rápida de la vegetación en los bosques secos de La Ceiba y Cordillera Arañitas, provincia de Loja, Ecuador. In: Vásquez MA, Larrea M, Suárez L et al (eds) Biodiversidad en los bosques secos del sur-occidente de la provincia de Loja. EcoCiencia, Ministerio del Ambiente, Herbario LOJA y Proyecto Bosque seco, Quito

Aguirre Z, Madsen JE, Cotton E et al (eds) (2002) Botánica austroecuatoriana: estudios sobre los recursos vegetales en las provincias de El Oro, Loja y Zamora-Chichipe. Ediciones Abya Yala, Quito

Aguirre Z, Linares-Palomino R, Kvist LP (2006) Especies leñosas y formaciones vegetales en los bosques estacionalmente secos de Ecuador y Perú. Arnaldoa 13:324-350

Angiosperm Phylogeny Group (APG) (2003) An update of the Angiosperm Phylogeny Group classification for the orders and families of flowering plants: APG II. Bot J Linn Soc 141:399-436

Barneby RC (1998) Silktree, guanacaste, monkey's earring: a generic system for the synandrous Mimosaceae of the Americas. Part III. Calliandra. Mem N Y Bot Gard 74:1-223

Best B, Kessler M (1995) Biodiversity and conservation in Tumbesian Ecuador and Peru. BirdLife International, Cambridge

BirdLife International (2003) BirdLife's online World Bird Database: the site for bird conservation, version 2.0. BirdLife International, Cambridge. http://www.birdlife.org. Cited 19 Mar 2007

Borchsenius F (1997) Patterns of plant species endemism in Ecuador. Biodivers Conserv 6:379-399

Bracko L, Zarucchi J (1993) Catálogo de las Angiospermas y Gimnospermas del Perú. Monogr Syst Bot Mo Bot Gard 45:1-1286

CDC-UNALM (1992) Estado de conservación de la diversidad natural de la región noroeste del Perú. Universidad Nacional Agraria la Molina, Lima

Cerón CE (1996a) Estudio preliminar de plantas útiles del Parque Nacional Machalilla, provincia de Manabí-Ecuador. In: Cerón C (ed) Etnobotánica del Ecuador, 2nd edn. Abya Yala, Quito

Cerón CE (1996b) Diversidad, especies vegetales y usos en la Reserva Ecológica Manglares-Churute, Provincia de Guayas, Ecuador. Rev Geogr 36:1-92

Cerón CE (2002) Aportes a la flora útil de Cerro Blanco, Guayas-Ecuador. Cinchonia 3:17-25

Clark JL, Neill DA, Asanza M (2006) Floristic checklist of the Mache-Chindul mountains of Northwestern Ecuador. Contrib US Nat Herb 54:1-180

Davis S, Heywood VH, Hamilton AC (eds) (1997) Centres of plant diversity, vol 3: the Americas. IUCN, Gland

Dinerstein E, Olson DM, Gram DJ et al (1995) Una evaluación del estado de conservación de las ecoregiones de América Latina y Caribe. Banco Internacional de Reconstrucción y Fomento - Banco Mundial, Washington, DC

Dodson CH, Gentry AH (1991) Biological extinction in western Ecuador. Ann Mo Bot Gard 78:273-295

Ewel JJ (1986) Designing agricultural ecosystems for the humid tropics. Ann Rev Ecol Syst 17:245-271

Gentry AH (1982) Phytogeographic patterns as evidence for a Chocó refuge. In: Prance GT (ed) Biological diversification in the tropics. Columbia University Press, New York

Gentry AH (1993) Overview of the Peruvian flora. In: Brako L, Zarucchi JL (eds) Catalogue of the flowering plants and gymnosperms of Peru. Monogr Syst Bot Mo Bot Garden 45:xxix-xl

Gentry AH (1995) Diversity and floristic composition of neotropical dry forests. In: Bullock SH, Mooney HA, Medina E (eds) Seasonally dry tropical forests. Cambridge University Press, Cambridge

Hernández C, Josse C (1997) Plantas silvestres comestibles del Parque Nacional Machalilla. Hombre y Ambiente, Abya-Yala, Quito 40:1-78

Hocquenghem AM (1998) Para vencer la muerte. Piura y Tumbes. Raíces en el bosque seco y en la selva alta - Horizontes en el Pacífico y en la Amazonia. CNRS, IFEA, INCAH, Lima

Honorio E (2006) Floristic relationships of the tree flora of Jenaro Herrera, an unusual area of the Peruvian Amazon. MSc Thesis, University of Edinburgh and the Royal Botanic Garden, Edinburgh

IUCN (2006) 2006 IUCN red list of threatened species. http://www.iucnredlist.org. Cited 6 Mar 2007

Jarvis A, Reuter HI, Nelson A et al (2008) Hole-filled SRTM for the globe version 4. The CGIAR Consortium for Spatial Information (CGIAR-CSI) SRTM 90m Database. http://srtm.csi.cgiar.org. Cited 12 Sep 2008 
Jørgensen PM, León-Yánez S (eds) (1999) Catalogue of the vascular plants of Ecuador. Monogr Syst Bot Mo Bot Gard 75:i-viii, 1-1182

Josse C (1997) Dinámica de un bosque seco, semideciduo y secundario en el oeste del Ecuador. In: Valencia R, Balslev H (eds) Estudios sobre diversidad y ecología de plantas. Pontificia Universidad Católica del Ecuador, Quito

Josse C, Balslev H (1994) The composition and structure of a dry, semidecidious forest in western Ecuador. Nord J Bot 14:425-433

Killeen TJ, Chavez E, Peña-Claros M (2006) The Chiquitano dry forest, the transition between humid and dry forest in eastern lowland Bolivia. In: Pennington RT, Lewis GP, Ratter JA et al (eds) Neotropical savannas and seasonally dry forests: plant diversity, biogeography and conservation. CRC Press, Florida

Klitgaard B, Lozano P, Aguirre Z et al (1999) Composición florística y estructural del bosque petrificado de Puyango. Herbario Loja 3:25-49

Kvist LP, Skog LE, Clark JL et al (2004) The family Gesneriaceae as example for the biological extinction in Western Ecuador. Lyonia 6:127-151

León B, Roque J, Ulloa Ulloa C et al (eds) (2006) El libro rojo de las plantas endémicas del Perú. Rev Peru Biol 13:1-966

Linares-Palomino R, Ponce-Alvarez SI (2005) Tree community patterns in seasonally dry tropical forests in the Cerros de Amotape Cordillera, Tumbes, Peru. For Ecol Manag 209:261-272

Linares-Palomino R, Pennington RT, Bridgewater S (2003) The phytogeography of the seasonally dry tropical forests in Equatorial Pacific South America. Candollea 58:473-499

López RP (2003) Diversidad y endemismo de los valles secos de Bolivia. Ecol Bolivia 38:28-60

López RP, Zambrana-Torrelio C (2006) Representation of Andean dry ecoregions in the protected areas of Bolivia: the situation in relation to the new phytogeographical findings. Biodivers Conserv 15:21632175

Lott EJ, Atkinson TH (2006) Mexican and Central American seasonally dry tropical forests: ChamelaCuixmala, Jalisco, as focal point for comparison. In: Pennington RT, Lewis GP, Ratter JA (eds) Neotropical savannas and seasonally dry forests: plant diversity, biogeography and conservation. CRC Press, Florida

Lozano PE (2002) Los tipos de bosques en el sur de Ecuador. In: Aguirre Z, Madsen JE, Cotton E et al (eds) Botánica Austroecuatoriana: Estudios sobre los recursos vegetales en las provincias de El Oro, Loja y Zamora. Abya Yala, Quito

Madsen JE, Mix R, Balslev H (2001) Flora of Puná Island. Plant resources on a neotropical island. Aarhus University Press, Denmark

Mittermeier RA, Gil PR, Hoffman M et al (2005) Hotspots revisited: earth's biologically richest and most threatened terrestrial ecoregions. Conservation International, Washington, DC

Myers N, Mittermeier RA, Mittermeier CG et al (2000) Biodiversity hotspots for conservation priorities. Nature 403:853-858

Nuñez T (1997) Inventario florístico y zonificación de la vegetación en la Isla de la Plata, Parque Nacional Machalilla. In: Valencia R, Balslev H (eds) Estudios sobre diversidad y ecología de plantas. Pontificia Universidad Católica del Ecuador, Quito

Olson DM, Dinerstein E (2002) The global 200: priority ecoregions for global conservation. Ann Mo Bot Gard 89:199-294

Olson DM, Dinerstein E, Wikramanayake ED et al (2001) Terrestrial ecoregions of the world: a new map of life on earth. BioScience 51:933-938

Ortlieb L, Macharé J (1993) Former El Niño events: records from western South America. Global Planet Change 7:181-202

Parker TA, Carr JL (eds) (1992) Status of the forest remnants in the Cordillera de la Costa and Adjacent areas of Southwestern Ecuador. Rapid assessment program working paper 2. Conservation International, Washington, DC

Parker TA, Schulenberg TS, Graves GR et al (1985) The avifauna of the Huancabamba region, northern Peru. In: Buckley PA, Foster MS, Morton ES et al (eds) Neotropical ornithology. Ornith Monogr 36:169-197

Pennington RT, Ratter JA, Lewis GP (2006) An overview of the plant diversity, biogeography and conservation of neotropical savannas and seasonally dry forests. In: Pennington RT, Lewis GP, Ratter JA (eds) Neotropical savannas and seasonally dry forests: plant diversity, biogeography and conservation. CRC Press, Florida

Peralvo M, Sierra R, Young KR et al (2007) Identification of biodiversity conservation priorities using predictive modeling: an application for the Equatorial Pacific region of South America. Biodivers Conserv 16:2649-2675 
Queiroz LP (2006) The Brazilian caatinga: phytogeographical patterns inferred from distribution data of the Leguminosae. In: Pennington RT, Lewis GP, Ratter JA (eds) Neotropical savannas and seasonally dry forests: plant diversity, biogeography and conservation. CRC Press, Florida

Rzedowski J (1991) El endemismo en la flora fanerogámica mexicana: una apreciación analítica preliminar. Acta Bot Mex 15:47-64

Sagástegui A (1995) Diversidad florística de Contumazá. Editorial Libertad, Trujillo

Silva RA, Santos AMM, Tabarelli M (2003) Riqueza e diversidade de plantas lenhosas em cinco unidades de paisagem da Caatinga. In: Leal IR, Tabarelli M, Silva JMC (eds) Ecologia e conservação da caatinga. Ed. Universitária da UFPE, Recife

Svenson HK (1946) Vegetation of the coast of Ecuador and Peru and its relation to the Galápagos Islands. Am J Bot 33:394-498

The Nature Conservancy, Fundación Agua, EcoCiencia et al (2004) Portafolio de sitios prioritarios para la conservación dentro de la unidad de planificación ecorregional Pacífico Ecuatorial, Quito. http://conserveonline.org/workspaces/pe_era. Cited 17 Aug 2007

Ulloa Ulloa C, Neill DA (2005) Cinco años de adiciones a la flora del Ecuador. 1999-2004. Universidad Técnica Particular de Loja, Missouri Botanical Garden, FunBotanica, Loja, Ecuador

Ulloa Ulloa C, Zarucchi JL, León B (2004) Diez años de adiciones a la flora de Perú. Arnaldoa, ed. especial, Nov 2004

UNESCO-MAB (2002) Seville+5 Recommendations: Checklist for Action. http://unesdoc.unesco.org/ images/0012/001266/126629e.pdf\#xml=http://unesdoc.unesco.org/ulis/cgi-bin/ulis.pl?database=ged\& set=44115CBA_0_13\&hits_rec=9\&hits_lng=eng. Cited 29 July 2009

Valencia R, Pitman NS, Léon-Yánez S (eds) (2000) Libro rojo de las plantas endémicas del Ecuador. Herbario QCA, Pontificia Universidad Católica del Ecuador, Quito

van der Werff H, Consiglio T (2004) Distribution and conservation significance of endemic species of flowering plants in Peru. Biodivers Conserv 13:699-713

Venegas PJ (2005) Herpetofauna del bosque seco ecuatorial de Perú: taxonomía, ecología y biogeografía. Zonas Áridas 9:9-26

Weberbauer A (1945) El mundo vegetal de los Andes peruanos. Editorial Lume, Lima-Peru

Wilson EO (1992) The diversity of life. Harvard University Press, Cambridge

Wood JRI (2006) Inter-Andean dry valleys of Bolivia-floristic affinities and patterns of endemism: insights from Acanthaceae, Asclepiadaceae and Labiatae. In: Pennington RT, Lewis GP, Ratter JA (eds) Neotropical savannas and seasonally dry forests: plant diversity, biogeography and conservation. CRC Press, Florida 